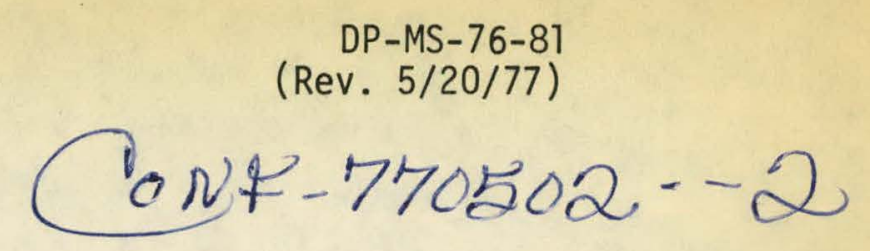

\title{
A STRESS CORROSION CRACKING TEST WITH SLOW STRAIN RATE AND CONSTANT CURRENT
}

by

R. S. Ondrejcin

Savannah River Laboratory

E. I. du Pont de Nemours \& Co.

Aiken, SC 29801

A paper accepted for presentation at the

ASTM Symposium on Stress Corrosion Cracking --

The Constant Strain Rate Technique

May 1-6, 1977

Toronto, Canada

and for publication in the proceedings

This paper was prepared in connection with work under Contract No. AT(07-2)-1 with the U.S. Energy Research and Development Administration. By acceptance of this paper, the publisher and/or recipient acknowledges the U.S. Government's right to retain a nonexclusive, royalty-free license in and to any copyright covering this paper, along with the right to reproduce and to authorize others to reproduce all or part of the copyrighted paper. 


\section{DISCLAIMER}

This report was prepared as an account of work sponsored by an agency of the United States Government. Neither the United States Government nor any agency Thereof, nor any of their employees, makes any warranty, express or implied, or assumes any legal liability or responsibility for the accuracy, completeness, or usefulness of any information, apparatus, product, or process disclosed, or represents that its use would not infringe privately owned rights. Reference herein to any specific commercial product, process, or service by trade name, trademark, manufacturer, or otherwise does not necessarily constitute or imply its endorsement, recommendation, or favoring by the United States Government or any agency thereof. The views and opinions of authors expressed herein do not necessarily state or reflect those of the United States Government or any agency thereof. 


\section{DISCLAIMER}

Portions of this document may be illegible in electronic image products. Images are produced from the best available original document. 
A STRESS CORROSION CRACKING TEST WITH

SLOW STRAIN RATE AND CONSTANT CURRENT*

R. S. Ondrejcin

Savannah River Laboratory

E. I. du Pont de Nemours \& Co.

Aiken, SC 29801

\section{ABSTRACT}

A rapid e1 ertrochomical tonjile test was developed for evaluating stress corrosion crack initiation in carbon steel. Constant anodic current was imposed on smooth-bar tensile specimens as the specimens were slowly strained to fracture at cross-head speeds of $1.3 \times 10^{-6} / \mathrm{sec}$. Equivalent response results were obtained for all ductility properties measured; uniform elongation, total elongation, and reduction of area. Total elongation was chosen as the index for stress corrosion crack initiation. An equation was developed that allowed calculation of tulal elongation of specimens in electrolytes (test solutions) with composition ranges of 1.5 to $5.5 \mathrm{M}$ nitrate, 0 to $3.5 \mathrm{M}$ nitrite, and 0 to $5.0 \mathrm{M}$ hydroxide, and a temperature range of 50 to $100^{\circ} \mathrm{C}$. A minimum of $13 \%$ total elongation was selected to indicate the possible initiation of cracking in A 285-B steel alloy.

* The information contained in this article was developed during the course of work under Contract No. AT (07-2)-1 with the U.S. Energy Research and Development Administration. 
The test was used to evaluate relative aggressiveness of synthetic nuclear wastes on A 285-B carbon steel and the relative resistances of several steels to given solution compositions. Test results formed one of the bases for setting temperature limits and concentration limits for several ions in nuclear wastes that are stored in carbon steel tanks at the Savannah River Plant.

\section{KEY WORDS}

Stress Corrosion, Nitrate Stress Corrosion, Stress Corrosion Cracking Tests, Slow Strain Rate and Constant Current, Mechanical Tests, Carbon Steels, Waste Disposal, Radioactive Wastes, Mathematical Auralysis.

\section{INTRODUCTION}

Background

The carbon steel that is the main structural material in tanks used for storing wastes from nuclear fuel reprocessing at the Savannah River Plant (SRP) is susceptible to stress corrosion cracking in nitrate or hydroxide solutions. The primary carbon steel shells of nine of sixteen older, non-stress relieved, doubleshell tanks at SRP have leaked. Stress corrosion cracking was identified $^{1}$ as the cause of leaks in five tanks and is assumed to be the cause of leaks in the other four. Cracks normally have sealed themselves when the leaking liquid, an lakaline nitrate solution, dried on the exterior wall of the primary container. The seven newest waste tanks constructed at SRP are heat treated to relieve stresses accumulated during construction, thereby minimizing potential for stress-corrosion cracking. No leaks have occurred in the seven stress-relieved, double-shell tanks at SRP. 
Standard stress corrosion specimens such as welded or notched, three-point-loaded or U-bend samples have not cracked in the actual alkaline nitrate wastes, although waste tanks containing apparently equivalent solutions cracked after 0.5 to 15 years. The absence of specimen cracking was assumed to mean that standard specimens were not sufficiently susceptible to cracking in a reasonable period of time. A test was therefore required to evalute the effects of a large number of variables, including temperature and the concontrations of many ions in the waste sulutions, on initiation of stress corrosion cracking. Results of such a test help to define operating 1 imits of temperature and composition of waste solution so as to avoid further stress corrosion cracking of waste tanks.

Corrosion of Specimens Undergoing Strain

Tests of specimens undergoing strain, either with or without electrochemical control, have been used by a number of investigators to study the mechanism of stress corrosion, often for carbon steel. Early stress corrosion experiments showed the importance of plastic flow and the more rapid attack at grain boundaries in the presence of stress. ${ }^{2}$ Susceptibility of carbon steel to stress corrosion by migration of impurities to and from grain boundaries has also been tested by the constant strain rate techniques. ${ }^{3}$ Grain boundaries that were pure underwent attack because of high free energy, but commerical steels with high-impurity grain boundaries were attacked much more rapidly because the impurities made the 
grain boundaries anodic.. Constant strain rate stress corrosion tests verified the prediction of polarization measurements that carbonate ion would attack carbon steel intergranularly, and the potential and concentration ranges where cracking occurred were determined. ${ }^{4}$

Strain rate appears to have a direct influence on crack velocity in iron alloys. ${ }^{5}$ In titanium alloy systems, the effect of low strain rate on cracking susceptibility has been shown to depend on repassivation kinetics. ${ }^{6}$ Experiments with high constant. strain rates have been used to study the anodic behavior of mild steel in nitrate solutions. ${ }^{7}$ High anodic current densities were observed when the oxide film fractured under controlled potential. At low strain rates, stress corrosion "cracks" were observed.

Stress Corrosion in the Presence of Slow Strain Rate and Constant Current

The constant strain rate test described in this paper was devised to study the corrosive effect of complex nuclear waste solutions on carbon stcel. Elcctrochemical control was used to accelerate the attack. Current was controlled, rather than potential, because corrosion requires current flow rather than potential difference. The current level was chosen on the basis of potentiodynamic polarization curves. Arguments have already been advanced to the effect that stress corrosion cracking is caused by a current flow over a given period of time, i.e., by a given quantity of current, and that stress corrosion is also related to the time required for passivation. ${ }^{8}$ 
DP-MS-76-81

\section{TEST PROCEDURES AND EQUIPMENT}

Polarization curves were determined with a Princeton Applied Research Model 173 potentiostat combined with a Houston Model $2000 X-Y$ recorder. Data points for the curves were normally determined at $100^{\circ} \mathrm{C}$, occasionally at $50^{\circ}$ or $75^{\circ} \mathrm{C}$. A standard ASTM G 5-72 polarization cell was used for non-radioactive solutions. A smaller cell, similar in design and cross checked against the standard cell, was used for radioactive samples.

The special electrochemical tensile test coll was machined from Teflon* as shown in Figure 1. The cell contains the test sample immersed in the test solution (electrolyte). The sample is a standard tensile specimen with a $31.7-\mathrm{mm}$ gage length; the load is applied with a hard beam machine (Instron Model TT-C-L) at an initial strain rate of $1.3 \times 10^{-6} / \mathrm{sec}$. A platinum counter electrode (cathode with one lead connected to the potentiostat surrounds the sample. The cell is connected to a saturated calomel reference electrode by a Teflon-covered string salt bridge which enters the top of tlie cell and is positioned within $2 \mathrm{~mm}$ of the sample. The other end of the bridge is immersed in a beaker containing test solution and the reference electrode at room temperature. The reference electrode lead is the second connection to the potentiostat, and the lead from the threaded portion of the specimen is the third. An environmental chamber controls the temperature of the test specimen, cell, and solution

* Trademark, E. I. du Pont de Nemours and Company, Inc., Wilmington, Me1. 
to within $\pm 1^{\circ} \mathrm{C}$. Change in solution concentration by evaporation during testing is prevented by a total-reflux condenser connected to the cell.

Current flow between the counter electrode (platinum sheet) and working electrode (tensile specimen) is controlled by the potentiostat to within about $1 \%$ of the preset value. Values of either $0.20 \mathrm{~mA} / \mathrm{cm}^{2}$ or $0.5 \mathrm{~mA} / \mathrm{cm}^{2}$ were selected because they represented currents that would be expected with the steel in some waste solutions if a $0.01-\mathrm{V}$ local potential difference existed. The se currents were based on polarization curves which were developed for the steel in various actual waste supernates. Stress corrosion cracking tests were performed on specimens machined from a single plate of ASTM A 285-B steel originally used in the fabrication of one of the SRP nuclear waste tanks. This grade is a hot-rolled, plain carbon steel of pressure vessel quality. The microstructure of the steel is shown in Figure 2 . The composition of the steel is given in Table 1 . Longitudinal tensile test spocimons were machined from this steel to a $63-\mathrm{rms}$ surface finish as illustrated in Figure 3 . The specimen has a diameter that would require it to be about half as long to be a sma11-size specimen proportional to the ASTM standard 0.5-round x 2-in. gage-length tension test specimen. Prior to testing, specimens were vapor-degreased in benzene, rinsed in acetone, and dried in air. 


\section{EXPERIMENTAL WORK}

\section{Corrosion Reactions and Effects of Potential}

Corrosion reactions that occur during cracking of carbon steel in nitrate solutions are not agreed upon.. Steel is proposed to react according to

$$
10 \mathrm{Fe}+6 \mathrm{NO}_{3}^{-}+3 \mathrm{H}_{2} \mathrm{O} \rightarrow 5 \mathrm{Fe}_{2} \mathrm{O}_{3}+6 \mathrm{OH}^{-}+3 \mathrm{~N}_{2}
$$

by Engell and Baume $1^{9}$ or, after oxidation of the iron to ferrous ion, by the reaction

$$
2 \mathrm{Fe}^{2+}+\mathrm{NO}_{3}^{-}+\mathrm{H}_{2} \mathrm{O} \rightarrow 2 \mathrm{Fe}^{3+}+\mathrm{NO}_{2}^{-}+2 \mathrm{OH}^{-} .
$$

as proposed by Smialowski, et al., ${ }^{10}$ or anodically by the reaction

$3 / 4 \mathrm{Fe}+\mathrm{H}_{2} \mathrm{O} \rightarrow 1 / 4 \mathrm{Fe}_{3} \mathrm{O}_{4}+2 \mathrm{H}^{+}+2 e^{-}$

According to Hoar and Galvele, ${ }^{7}$ at least two cathodic reactions probably take place, with the resultant being

$$
\mathrm{NO}_{3}^{-}+\mathrm{H}_{2} \mathrm{O}+2 \mathrm{e}^{-} \rightarrow \mathrm{NO}_{2}^{-}+2 \mathrm{H}^{-}
$$

On the basis of Equations 3 and 4 , the $\mathrm{H}^{+}$produced in the anodic reaction and the $\mathrm{OH}^{-}$produced in the cathodic reaction may react, depending on the distances between the anode and cathode. If the electrode surfaces are separated, e.g., if the anode is the tip of a crack or the bottom of a pit, and the cathode is the wall of the crack or pit, the anode becomes more acidic and the cathode more basic.

Stress corrosion work at the Naval Research Laboratory (NRL) has shown that during cracking of a number of high-strength steels, the tip of the crack becomes acidic, 11 as inferred from Equation 3. Measurements showed the solutions at the crack tip consistently 
to have a $\mathrm{pH}$ of $\sim 3$. NRL concluded that the $\mathrm{pH}$ was controlled by the hydrolysis of the ferrous iron, i.e., that the reaction

$$
\mathrm{Fe}^{2+}+\mathrm{HOH} \rightarrow \mathrm{Fe}(\mathrm{OH})^{+}+\mathrm{H}^{+}
$$

was controlling.

Parkins and Ushe $\mathrm{r}^{12}$ showed that in nitrate solutions the severity of cracking increases according to the cation series $\mathrm{Na}^{+}<\mathrm{Ca}^{2+}<\mathrm{NH}_{4}^{+} .^{12}$ In addition to causing greater cracking, this series is also one of increasing acidity which causes the open-circuit potential of the steel to becomo morc and muie anodic. ${ }^{7}$ Increasing anodic potential either increases anodic current density or stimulates cathodic reactions.

Corrosion, the precursor to cracking, is normally under the control of cathodic reactions in aqueous solutions ${ }^{13}$ and is relatively unaffected by minor changes in steel composition. The rate is influenced by the reduction kinetics and diffusion of reactants to cathodic sites. Nitrate, which takes part in the cathodic reaction, is more easily reduced as the solution becomes morc acidic.

To reduce nitrate stress corrosion cracking, the best theoretcal approach, on the basis of Equations 1 through 4, is to reduce the cathodic reaction. Cathodic reaction can be reduced either by increasing the concentration of $\mathrm{OH}^{-}$alone or by increasing the $\mathrm{OH}^{-}$and $\mathrm{NO}_{2}^{-}$concentrations together. 
DP-MS-76-81

Investigation of Corrosion of SRP Waste Tanks

To determine whether cracking of SRP waste tanks was actually caused by nitrate corrosion, the open-circuit potentials of four SRP waste tanks containing alkaline nitrate radioactive wastes were measured against saturated calomel electrodes (SCE). The potentials were $-0.44 \mathrm{~V},-0.12 \mathrm{~V},-0.085 \mathrm{~V}$, and $-0.064 \mathrm{~V}$. These potentials fall generally in the range for cracking in pure $4 \mathrm{M}$ sodium nitrate $(-0.30$ to $+1.10 \mathrm{~V})$ rather than for cracking in hydroxide, which would be expected to occur in the range -0.90 to $-1.04 \mathrm{~V}$.

\section{Waste Solution Compositions}

A large number of supernate samples were taken from fourteen SRP waste tanks and analyzed to determine general compositions and specifically the nitrate concentration. The samples represented about 42 million liters (11 million gallons) of radioactive waste. Measured concentration ranges are shown in Table 2 .

Polariantion Curveo

The effects causing stress corrosion in SRP waste supernates are expected to be maximized in a tensile test under electrochemical control. Stress is at its maximum because the sample is being strained continuously. Electrochemical control is expected to cause crack initiation at the normal locations and also to accelerate the process. Initiation of mild steel cracking by nitrate solutions is believed to involve carbon in the steel. ${ }^{14}$ 
Carbon, when present either in solid solution or as $\mathrm{Fe}_{3} \mathrm{C}$ in the steel grain boundaries, acts as an efficient cathode. This cathodic action stimulates anodic dissolution very close to the cathode, forming a micropit or trench, the precursor of a crack. Anodic dissolution of the grain boundaries can al so be stimulated by electrochemical control if a positive current flows through a test sample.

Current flows that can be expected from metals in solution are defined by anndir polariation curves. IIl certuin solutions where the metal shows an active-passive transition, such as mild steel in some SRP wastes, relatively high current flows can be caused by small potential differences.

Polarization curves run on actual alkaline nitrate wastes in shielded facilities showed that carbon steel normally acted as an active-passive metal. These curves and curves subsequently obtained with synthetic wastes are shown in Figure 4 . The curves for synthetic and actual wastes were so close together that the two soluliuns would be expected to cause equivalent corrosion. Therefore, synthetic solutions were used in further testing. The use of synthetic wastes provided a less difficult, faster, and less expensive approach in testing. 


\section{Electrochemical Tensile Test Results}

Plackett-Burman Series ${ }^{15}$

To determine which independent variables were most effective in causing nitrate stress corrosion cracking, a statistically designed series of experiments, known as the Plackett-Burman series, was performed using the electrochemical tensile test described above. This experimental design is generally used for screening a variable space in elected portions of a $2^{\mathrm{n}}$ factorial design where one variable is changed at a time with a high and a low value for each. As a screening design, the Plackett-Burman series has the advantage that a small number of experiments are required to investigate a large number of independent variables; it has the disadvantage of eliminating interaction effects. Thus, the possible combined effect of nitrite or hydroxide ions to reduce stress corrosion cracking predicted by Equations 1 through 4 would not be seen.

Because many independent variables can affect the cracking, the Plackett-Burman test series included seven independent variables; temperature and six anionic concentrations. This approach required only 12 experiments rather than 128 for a two-level $2^{\text {n }}$ factorial design. The variables are shown in Table 3 .

Four dependent variables, ultimate tensile strength (UTS) and three measures of ductility, were chosen as values that might be affected by the independent variables based on a stress-strain curve. 
Analyses of the Plackett-Burman data showed that temperature and $\mathrm{NO}_{3}^{-}$concentration stood out above interactions and experimental error in affecting ductility parameters. All three ductility variables correlated (at the $90 \%$ confidence level) with the experimental variation in temperature and $\mathrm{NO}_{3}^{-}$concentration. However, no statistically significant correlation was found between UTS and any of the independent variables. The large minimum factor effect (12) required for correlation of UTS with any independent variable versus the small minimum factor effect (four for elongation) required for correlation to ductility measurements indicate that an apparently inflated experimental error in UTS was caused by ion interactions. The minimum factor effect required for correlation would be four for both strength and ductility correlations, if its value were due only to experimental error.

Hydroxide concentration was believed to be the most likely ion to inflate the minimum factor effect required for correlation of strength with independent variables. To evaluate the hydroxide effect, a known inhibitor for nitrate stress corrosion, ultimate tensile strength, was measured in a series of electrochemical tensile tests. These strength data are plotted in Figure 5 against $\mathrm{OH}^{-}$concentration. Obviously there is a hydroxide effect; as hydroxide concentration increases, so does UTS. The lowest value observed was for high nitrate that was acidified with nitric acid. The next three were snythetic solutions 
representing fresh wastes from fuel reprocessing facilities and a hypothetical waste composition (H Purex) based on flow sheet calculations. The others were representative of wastes from actual waste tanks. Compositions of the solutions are given in Table 4 .

Metallographic examination of the cracked samples showed that the failures were typical of nitrate stress corrosion cracks as shown in Figure 6 . The cracks were intergranular and contained some loose grains and corrosion products, Fractographs showed that greatest damage occurred when the nitrate solutions contained the lowest concentrations of $\mathrm{NO}_{2}^{-}$and $\mathrm{OH}^{-}$. (Nitrite is a radiolysis product of nitrate.) Figure 7 shows that the sample in 221-F Purex (total $\mathrm{NO}_{2}^{-}$and $\mathrm{OH}^{-}$of $0.8 \mathrm{M}$ ) cracked along the gage length and failed with almost no reduction of area. The other two samples (total $\mathrm{NO}_{2}^{-}$and $\mathrm{OH}^{-} \geq 1.6 \mathrm{M}$ ) did not crack and showed more ductility with a shear fracture profile. Al1 fracture surfaces were severely corroded; in the 221-F Purex sample, intergranular separations were alsu prevalent, as were fracture surfaces characteristic of brittle rupture. The other two samples showed dimples resulting from microvoid formation typically of ductile fracture.

Box-Behnkin Series

The simultaneous effects of temperature, nitrate, nitrite, and hydroxide on strength and ductility were systematically evaluated using a Box-Behnkin series of experiments. ${ }^{16}$ The final 
result of this series of experiments is a response surface equation that correlates a dependent variable, such as ductility, to a series of independent variables, such as ionic concentrations. With independent variables specified, the dependent variable can be calculated once the equation is established.

The usual method of varying each variable individually (factorial design) to obtain an equation would have required prohibitively extensive testing as seen in Table 5. The conditions selected for the experimental series are shown in Table 6.

Temperature and nitrite were chosen on the basis of the Plackett-Burman series of experiments, and hydroxide and nitrite were chosen from actual test data (Figure 5) and previous work. Tests in appropriate combinations of the low, mean, and high values of the independent variables were run. The combinations were assigned to each test according to the standard four-variable Box-Behnkin design; the corresponding tensile tests were performed in random order.

In the tests, concenlraliuns of consticuents other than $\mathrm{NO}_{3}^{-}, \mathrm{NO}_{2}^{-}$, and $\mathrm{OH}^{-}$were held constant. One of the others, aluminate, is a major waste solution constituent and is known to have a significant effect on caustic cracking, probably because of the hydroxide concentration required to keep it in solution. However, aluminate ion apparently has at most a minor effect in nitrate stress corrosion cracking. Of the minor constituents, $\mathrm{SO}_{4}^{-}$and $\mathrm{Cl}^{-}$are often corroding agents and, therefore, 
could initiate the stress corrosion cracking sequence. Mercury changes the open-circuit potential of steel by 0.4 to $0.5 \mathrm{~V}$ in the positive direction and could put the steel in the potential range for nitrate cracking. The wastes also contain inhibitors such as $\mathrm{PO}_{4}^{3-}$ and $\mathrm{CrO}_{4}^{2-}$, some at high enough concentrations to inhibit corrosion in water. Therefore, these ions were included in the test solutions at a constant level which simulates the concentrations routinely found in waste solutions.

For the data reduction, a multiple regression, least squares program with the following features was used: 1) a full quadratic model, 2) an augmented correlation matrix to show correlation among all independent and dependent variables, and 3) analyses of residuals to reject results with large errors. The program also could plot dependent variables against each other to test whether the dependent variables measured the same or different effects. Other output data included equations representing the dependent variables and contour maps of the fitted dependent variables.

To imprnve the precision of the equations describing the response surfaces, especially in certain sections of the variable space, the Box-Behnkin data (27 tests) were combined with the Plackett-Burman data (12 tests) and five additional experiments were completed. Only one result of the 44 was rejected on the basis of the computer analysis of residuals; the remaining were used to establish the equations for the response surface. 
Cross plots of the four dependent variables showed that only two responses were present, one for UTS and one for ductility (total elongation, uniform elongation, or reduction of area). Thus, the same information would be obtained regardless of which ductility measurement was used. The correlations are shown in Table 7 .

The first response surface equation correlated UTS with changes in $\mathrm{NO}_{3}^{-}$and $\mathrm{OH}^{-}$concentration. The second equation for ductility was similar to the first, but more complex. Ductility correlated with temperature, nitrate, nitrite, and hydroxide, with the nitrate effect depending on temperature as well as on nitrite concentration.

The ductility response was chosen as the more important because stress corrosion is a phenomenon in which normally ductile material behaves in a brittle (less ductile) manner. The equation was developed specifically for total elongation because this is the simplest ductility property to measure in a tensile test. The equation is long (33 coefficients), but relatively simple in that it only has 1 inear, cross-product, and quadratic terms of the four independent variables.

\section{Correlation of Elongation to Stress Corrosion Cracking}

A minimum of $13 \%$ total elongation was selected to indicate the possible initiation of cracking for three separate, but related, reasons: 1) At $<13 \%$ total elongation, the specimens were always cracked. Above this value, cracking was unusual 
and, if observed, always minor. 2) Evaluation of tensile data in air showed that $13 \%$ elongation was the limit of uniform elongation at elevated temperatures. 3) The 13\% 1imit agreed with tests made by Donovan ${ }^{17}$ on wedge-opening-loaded (WOL) specimens over a limited range of variables. The WOL specimens were tested at $97^{\circ} \mathrm{C}$ in $5.0 \mathrm{M} \mathrm{NO}_{3}^{-}$solutions with 0 to $1.5 \mathrm{M} \mathrm{NO}_{2}^{-}$and 0 to $1.5 \mathrm{M} \mathrm{OH}^{-}$, and none of the minor constituents added. This agreement is shown in Figure 8. The WOL test differs from the electrochemical tensile test in that it measures crack growth rather than crack initiation. There is disagreement as to the effect of nitrite at low hydroxide levels, which may be due to the minor ions added in the electochemical tests. However, this portion of the data is not pertinent to waste tank operation, since hydroxide in waste solutions is $>0.3 \mathrm{M}$. The surface response relationship for elongation permits a rapid evaluation of whether SRP nuclear wastes might be expected to cause stress corrosion of carbon steels. The response equation is applicable in the four-dimensional space enclosed by the variables including temperature $\left(50-100^{\circ} \mathrm{C}\right)$, nitrate $(1.5-5 \mathrm{M})$, nitrite $(0-3,5 \mathrm{M})$, and hydroxide $(0-5.0 \mathrm{M})$. The $13 \%$ elongation limit for the initiation of cracking defines a value below which cracks may initiate. 


\section{APPL ICAT IONS}

The test described in this paper was used to establish compositional and temperature limits for waste tanks that presently store alkaline nitrate nuclear wastes at SRP. It was al so used to evaluate several varieties of carbon steel for tank construction. So far, four grades of mild steel have been examined and found to have increasing resistance to cracking in the order A 285-B, A-516-70 (as rolled), A 516-70 (normalized), and A 537 Class I. The latter two grades al so have improved fracture toüghness and were specified fur llew lank construction bcginning in 1976 .

\section{CONCLUSION}

A slow strain rate tensile test with constant current control was developed. This test is intended to evaluate the initiation phase of nitrate stress corrosion cracking of carbon steel. Experiments performed with this test in statistical formats identified the four most important factors involved in nitrate stress corrosion cracking of carbon steels. These factors are: temperature and the concentrations of nitrate, nitrite, and hydroxide ions. An equation for predicting total elongation of a steel from the four factors was developed. The total elongation was correlated to the crack initiation. Predicted data generally agreed with results of wOL tests performed in a portion of one plane of the tensile test data. 
DP-MS-76-81

\section{REFERENCES}

1. M. L. Hol zworth, et al. "How to Prevent Stress - Corrosion Cracking of Radioactive Waste Storage Tanks." Mater. Prot. 7, 36-38 (1968).

2. M. Henthorne and R. N. Parkins. "Some Aspects of Stress Corrosion Crack Propagation in Mild Steel." Corr. Sci. 6, $357(1966)$.

3. J. Flis and J. C. Scully. "The Role of Interstitial and Substitutional Impurities in Stress Corrosion Cracking of Low Carbon Steel in Nitrate Solution." Corrosion 24, 326 (1968).

4. J. M. Sutcliffe, et al. "Stress Corrosion Cracking of Carbon Steel in Carborate Solutions," Corrosion 28, 313 (1972).

5. R. N. Parkins. "Stress Corrosion Cracking and Hydrogen Embrittlement of Iron Base Alloys." Eds. R. D. McCright, J. E. Slates, and R. W. Staehle. National Association of Corrosion Engineers, Houston, TX. (to be published).

6. J. C. Scully and D. T. Powe11. "The Stress Corrosion Cracking Mechanism of $\alpha$ Titanium Alloys at Room Temperature." Corr. Sci. 10, 719 (1970).

7. T. P. Hoar and J. R. Galvele. "Anodic Behavior of Mild Steel During Yielding in Nitrate Solutions." Corr. Sci. 10, 211 $(1.970)$

8. J. C: Scully. "Stress Corrosion Crack Propogation, A Constant Charge Criterion." Corr. Sci., 15, 207 (1975). 
9. H. J. Engell and A. Bame1. "The Electrochemical Mechanism of Stress Corrosion Cracking of Mild Steel." p 341 in Physical Metallurgy of Stress Corrosion Fracture. T. N. Rhodin, ed. Interscience Publishers, New York (1959).

10. M. Smialowski and Z. Szklarska-Smialowski. "Corrosion of Iron in Solutions Containing Ammonium Nitrate." Corrosion 18, $1 \mathrm{t}(1962)$.

11. G. Sandoz, C. T. Fujii, and B. F. Brown. "Solution Chemistry Within Stress - Corrosion Cracks in Alloy Steels." Comp. Sci., 10, $839(1970)$.

12. R. N. Parkins and R. Usher. "The effect of Nitrate Solutions in Producing Stress Corrosion Cracking in Mild Stee1." p 289 in First Intermational Congress on Metallic Corrosion, Butterworth, London (1969).

13. R. A. Legault, S. Mori, and H. P. Leckie. "An Electrochemical Statistical Study of the Effect of Chemical Environment on the Corrosion Behavior of Mild Steel." Corrosion 6, 121 (1970).

14. R. N. Parkins. "Stress Corrosion Cracking of Low Carbon Steels." p 361 in Proceedings of Symposium - Fundamental Aspects of Stress Corrosion Cracking, 1967. National Association of Corrosion Engineers, Houston, Texas (1969).

15. R. L. Plackett and J. P. Burman. "The Design of Optimum Multifactorial Experiments." Biometrika 33, 505 (1946). 
16. G. E. P. Box and D. W. Behnkin. "Some New Three-Level Designs for the Study of Quantitiative Variables." Technometrics 2, 455-745 (1960).

17. J. A. Donovan. "Inhibition of Nitrate Stress Corrosion Cracking of Mild Steel in Nuclear Process Wastes." Trans. Am. NucZ. Soc. 21, 266 (1975). 
TABLE 1

ASTM A 285-B Cárbon Steel

\begin{tabular}{|c|c|c|c|c|c|c|}
\hline & Wt \% & & & & $\begin{array}{l}\text { Ultimate } \\
\text { Tensile } \\
\text { Strength, }\end{array}$ & $\begin{array}{l}\text { Elon- } \\
\text { gation }\end{array}$ \\
\hline & $\overline{M n}$ & $\bar{C}$ & $P$ & $S$ & $k p s i$ & \\
\hline Specification & $0.90^{a}$ & $0.22^{a}$ & $0.025^{a}$ & $0.045^{a}$ & $50-60$ & $25^{b}$ \\
\hline Actual analysis & 0.49 & 0.12 & 0.010 & 0.015 & 55.4 & 31 \\
\hline a. Maximum & & & & & & \\
\hline
\end{tabular}




\section{TABLE 2}

\section{Ionic Concentrations of SRP Waste Supernates}

$\begin{array}{ll}\text { Ion } & \begin{array}{l}\text { Concentration } \\ \text { Range, } M\end{array} \\ \mathrm{NO}_{3}^{-} & 1.6-4.5 \\ \mathrm{NO}_{2}^{-} & 0.5-3.2 \\ \mathrm{OH}^{-} & 0.8-6.3 \\ \mathrm{Al}^{-}(\mathrm{OH})_{4}^{-} & 0.4-1.6 \\ \mathrm{CO}_{3}^{2-} & <0.1-0.3 \\ \mathrm{SO}_{4}^{2-} & 0.02-0.20 \\ \mathrm{PO}_{4}^{3-} & 0.01-0.08 \\ \mathrm{Cl}^{-} & 0.005-0.11 \\ \mathrm{Cr}_{4}^{2-} & 0.001-0.009 \\ \mathrm{~F}^{-} & 0.001-0.004\end{array}$




\section{TABLE 3}

Plackett-Burman Variables and Constants

\begin{tabular}{|c|c|c|c|c|c|}
\hline \multirow{2}{*}{$\begin{array}{l}\text { Independent } \\
\text { Variables }\end{array}$} & \multicolumn{2}{|c|}{ Values $^{a}$} & \multirow{2}{*}{$\begin{array}{l}\text { Dependent } \\
\text { Variables }\end{array}$} & \multirow{2}{*}{\multicolumn{2}{|c|}{ Constants $a, c$}} \\
\hline & Low & High & & & \\
\hline Temp, ${ }^{\circ} \mathrm{C}$ & 50 & 100 & UTS & $\mathrm{CO}_{3}^{2-}$ & 0.1 \\
\hline $\mathrm{NO}_{3}^{-}$ & 1.5 & 5.5 & $\mathrm{TE}$ & $\mathrm{SO}_{4}^{2-}$ & 0.1 \\
\hline $\mathrm{NO}_{2}^{-}$ & 0 & 3.5 & UE & $\mathrm{PO}_{4}^{3-}$ & 0.05 \\
\hline $\mathrm{Al}(\mathrm{OH})_{i}^{-}$ & 0 & 1.6 & $\mathrm{R} \Lambda$ &. $\mathrm{CrO}_{4}^{2-}$ & 0.005 \\
\hline $\mathrm{OH}^{-}$ & 0 & 6.0 & & & \\
\hline $\mathrm{Cl}^{-}$ & 0.005 & 0.15 & & & \\
\hline $\mathrm{HHgO}_{\overline{2}}$ & 0 & 0.002 & & & \\
\hline
\end{tabular}

a. All ionic values are molar concentrations.

b. See Footnotes to Table 7 .

c. Added to simulate actual waste. 
TABLE 4

Analyses of Synthetic Waste Supernates

Ionic Concentration, $M$

Soln. Designation

H9 Salt

$\begin{array}{llll}1.9 & 3.2 & 2.8 & 1.6\end{array}$

0.10

0.02

0.0

$0.40 \quad 0.0 \quad \mathrm{ND}^{\alpha}$

0.03

0.003

$H g$,

221-F Purex

$2.9 \quad 0.0$

$0.8 \quad 0.5$

0.0

$0.04 \cdot 0.0 \quad$ ND

$0.01 \quad \mathrm{ND}$

221-H HM

$\begin{array}{ll}4.8 & 0.0\end{array}$

$0.3 \quad 1.5$

0.0

0.28

0.0

0.0

$0.00 \quad N D$

H Purex $b$

$\begin{array}{llll}7.4 & 0.0 & 0.5 & 0.0\end{array}$

0.01

0.03

0.0 ND

0.0

0.0

H11, Not Evaporated

$\begin{array}{llll}3.6 & 1.2 & 1.5 & 0.6\end{array}$

$\begin{array}{llll}0.07 \cdot 0.04 & 0.0 \quad \mathrm{ND}\end{array}$

$0.004 \quad 500$

H1 2, Not Evaporated

$\begin{array}{llll}3.0 & 1.2 & 1.4 & 0.4\end{array}$

0.06

$\begin{array}{lll}0.10 & 0.0 \quad \text { ND }\end{array}$

0.002200

H13, Not Evaporated

$\begin{array}{llll}3.7 & 0.25 & 1.4 & 0.16\end{array}$

0.10

0.07

0.0 ND

$0.001 \quad N D$

H32, Not Evaporated

$\begin{array}{llll}3.3 & 0.7 & 1.5 & 0.7\end{array}$

\begin{abstract}
0.10
\end{abstract}

$0.07 \quad 0.0$

$0.002 \quad 260$

a. Not determined.

b. A hypothetical composition calculated from the process flow sheet. All other compositions based on chemical analyses of actual solutions. 


\section{TABLE 5}

Factorial and Box-Behnkin Designs

\begin{tabular}{lll} 
Independent & Number of Experiments \\
\cline { 2 - 2 } $\begin{array}{l}\text { Variabies } \\
\text { Factorial }\end{array}$ & $\begin{array}{l}\text { Box-Behnkin } \\
\text { Design }\end{array}$ \\
3 & 27 & 15 \\
4 & 81 & 27 \\
5 & 243 & 46
\end{tabular}

TABLE 6

Box-Behnkin Conditions

\begin{tabular}{lllll}
$\begin{array}{l}\text { Independent } \\
\text { Variables }\end{array}$ & Range & $\begin{array}{l}\text { Dependent } \\
\text { Variables }\end{array}$ & \multicolumn{2}{l}{ Constants } \\
Temp, ${ }^{\circ} \mathrm{C}$ & $50-100$ & $\begin{array}{l}\text { Ultimate } \\
\text { Strength }\end{array}$ & $\mathrm{Al}(\mathrm{OH})_{4}^{-}$ & Sat. 0-1.5 \\
$\mathrm{NO}_{3}^{-}, \mathrm{M}$ & $1.5-5.5$ & $\begin{array}{l}\text { Total } \\
\text { Elongation }\end{array}$ & $\mathrm{CO}_{3}^{2-}$ & 0.1 \\
$\mathrm{NO}_{2}^{-} \mathrm{m} \mathrm{N}$ & $0-3.5$ & $\begin{array}{l}\text { Uniform } \\
\text { Elongation }\end{array}$ & $\mathrm{SO}_{4}^{2-}$ & 0.1 \\
$\mathrm{OH}^{-}, \mathrm{M}$ & $0-5.0$ & $\begin{array}{l}\text { Reduction } \\
\text { in Area }\end{array}$ & $\mathrm{PO}_{4}^{3-}$ & 0.05 \\
& & $\mathrm{CrO}_{4}^{2-}$ & 0.005 \\
& & $\mathrm{HHg0}_{2}^{-}$ & 0.002
\end{tabular}

$a$. Added to simulate actual wastes. 
TABLE 7

Dependent Variable Correlations

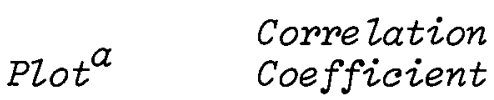

UE vs TE 0.9

$\begin{array}{ll}\text { RA vS TE } & 0.8\end{array}$

UE vS RA 0.7

UE vS UTS 0.5

TE vS UTS 0.5

RA va IITS 0.1

a. U - Uniform

T - Total

E - Elongation

RA - Reduction of Area

UTS - Ultimate Tensile Strength 


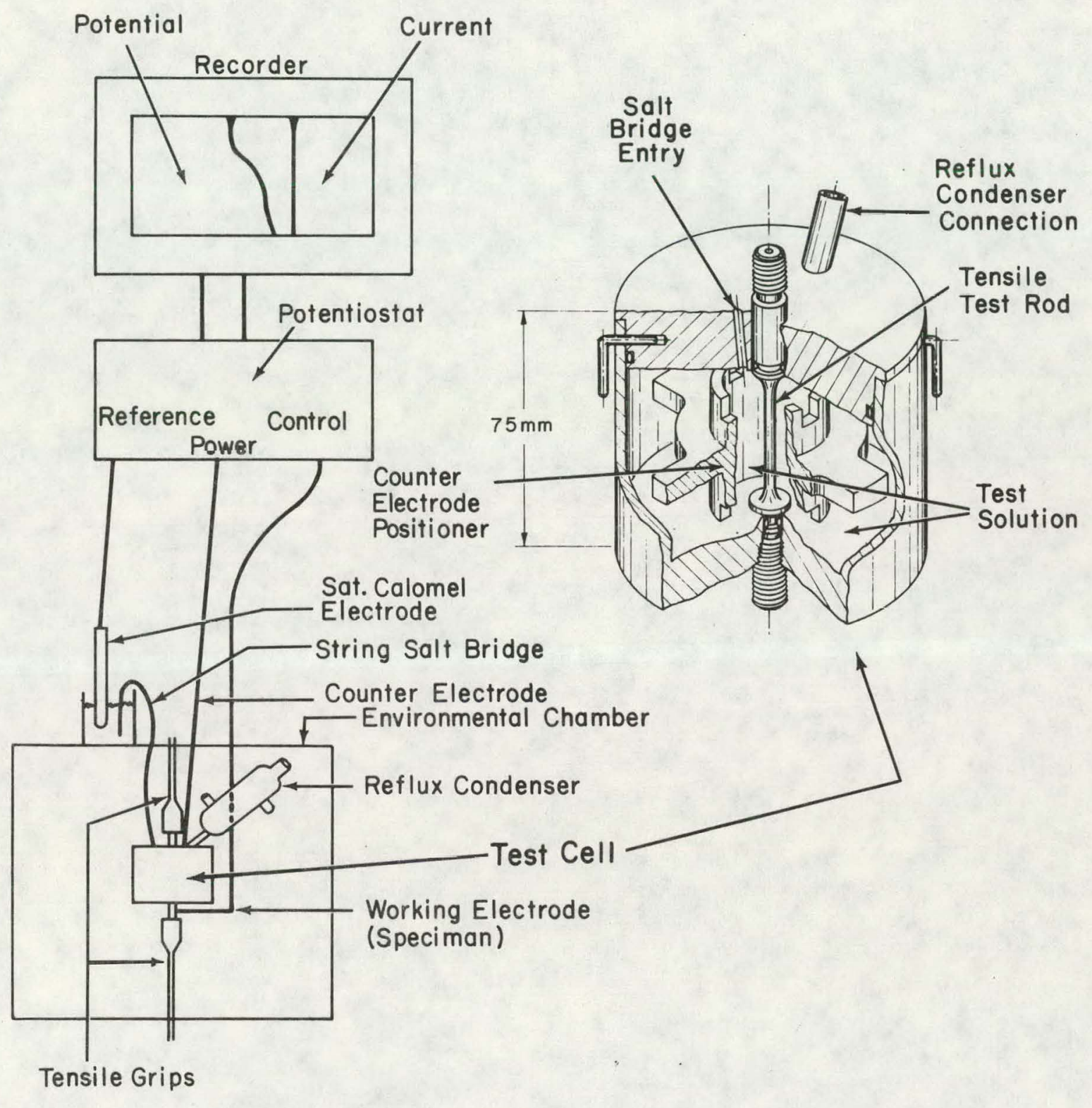

FIGURE 1. Electrochemical Tensile Test Equipment (Cell Material: Teflon) 


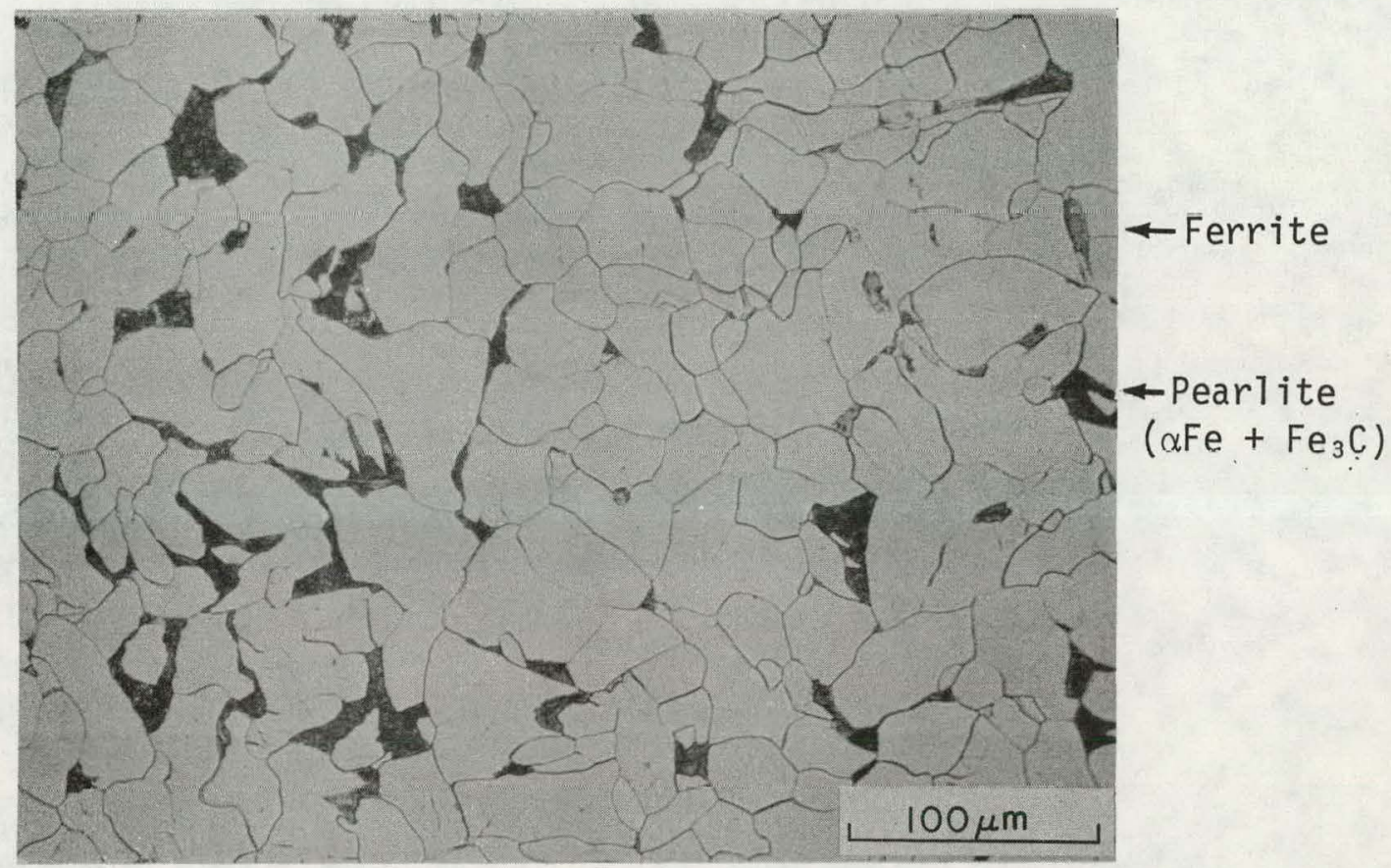

FIGURE 2. Longitudinal Microstructure of A 285-B Carbon Steel 


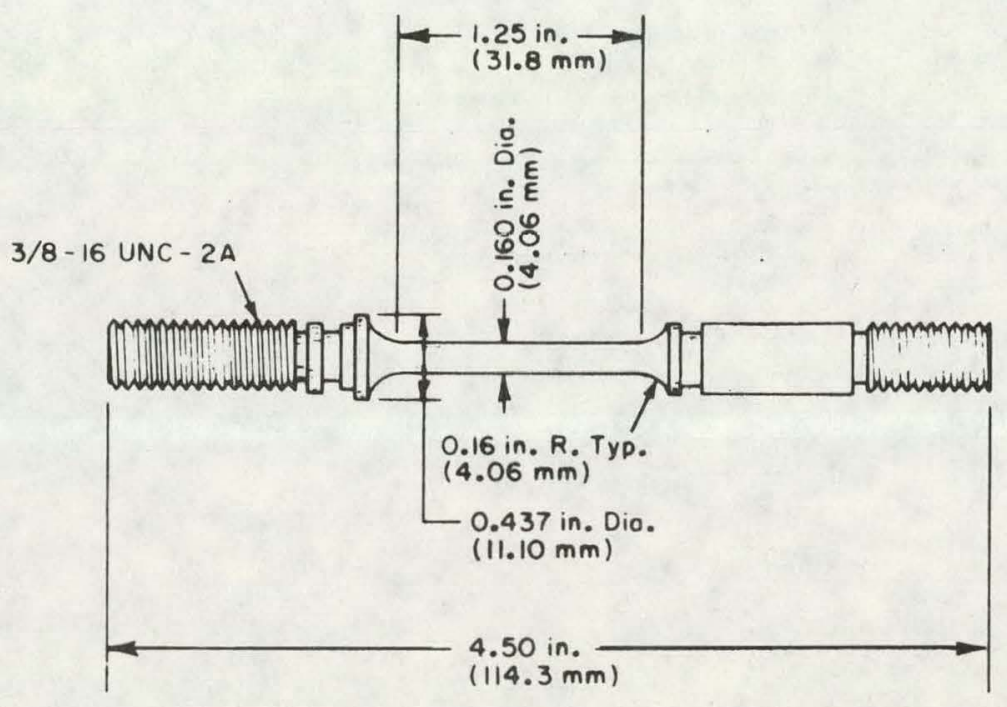

FIGURE 3. Tensile Test Specimen 


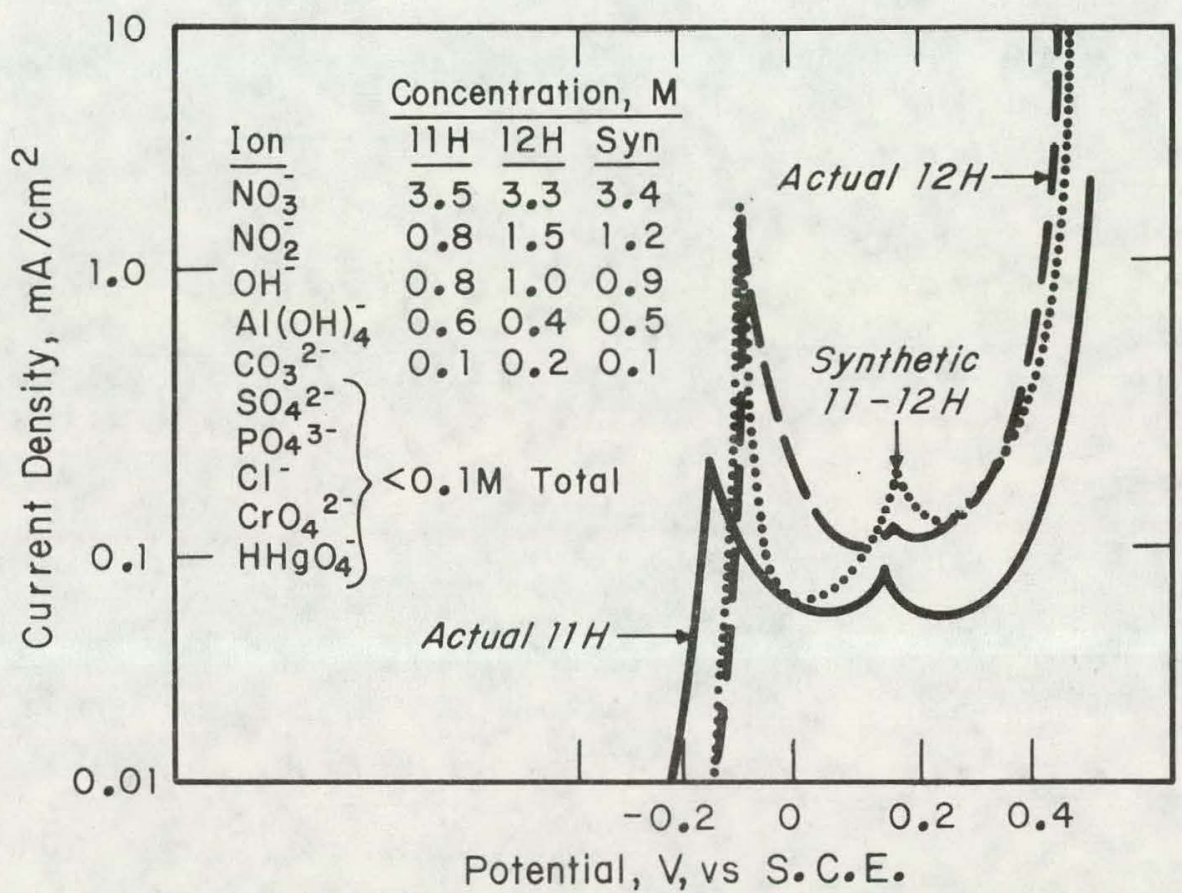

FIGURE 4. Anodic Potentiodynamic Polarization of A 285-B Carbon Steel in SRP Waste Supernate 


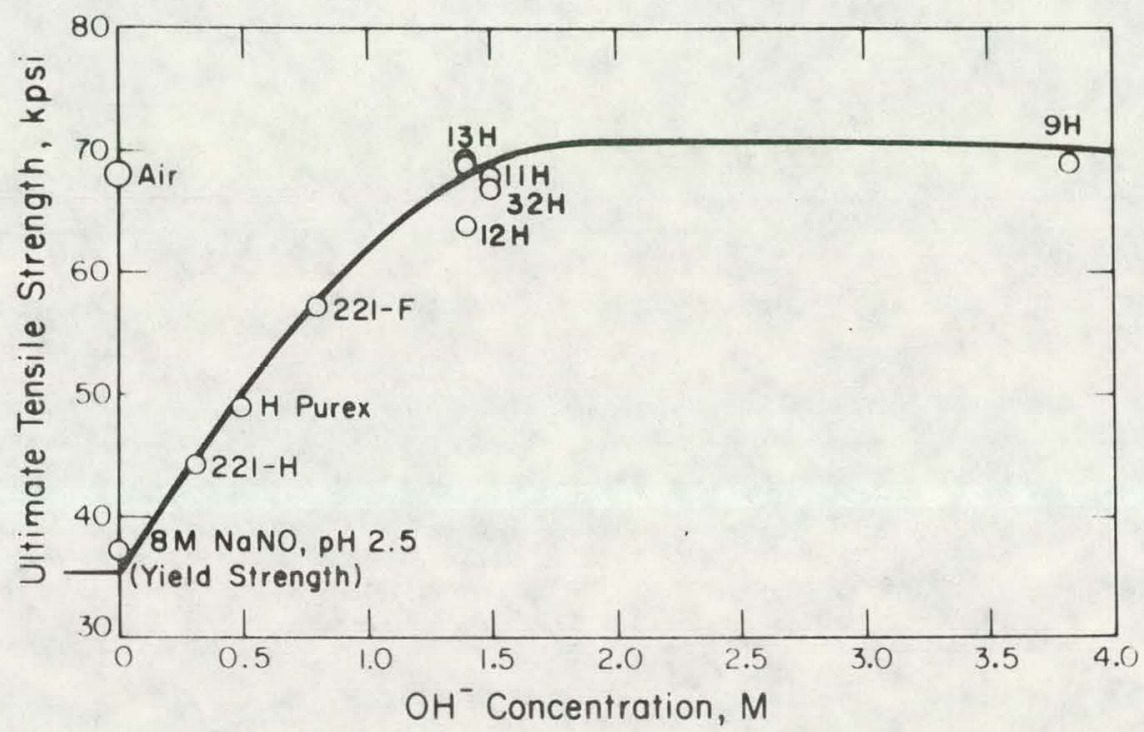

FIGURE 5. Electrochemical Tensile Test: Variation of Strength of 285-B Carbon Steel with Hydroxide Concentration, $100^{\circ} \mathrm{C}, 0.2 \mathrm{~mA} / \mathrm{cm}^{2}$ (See Table 4). 


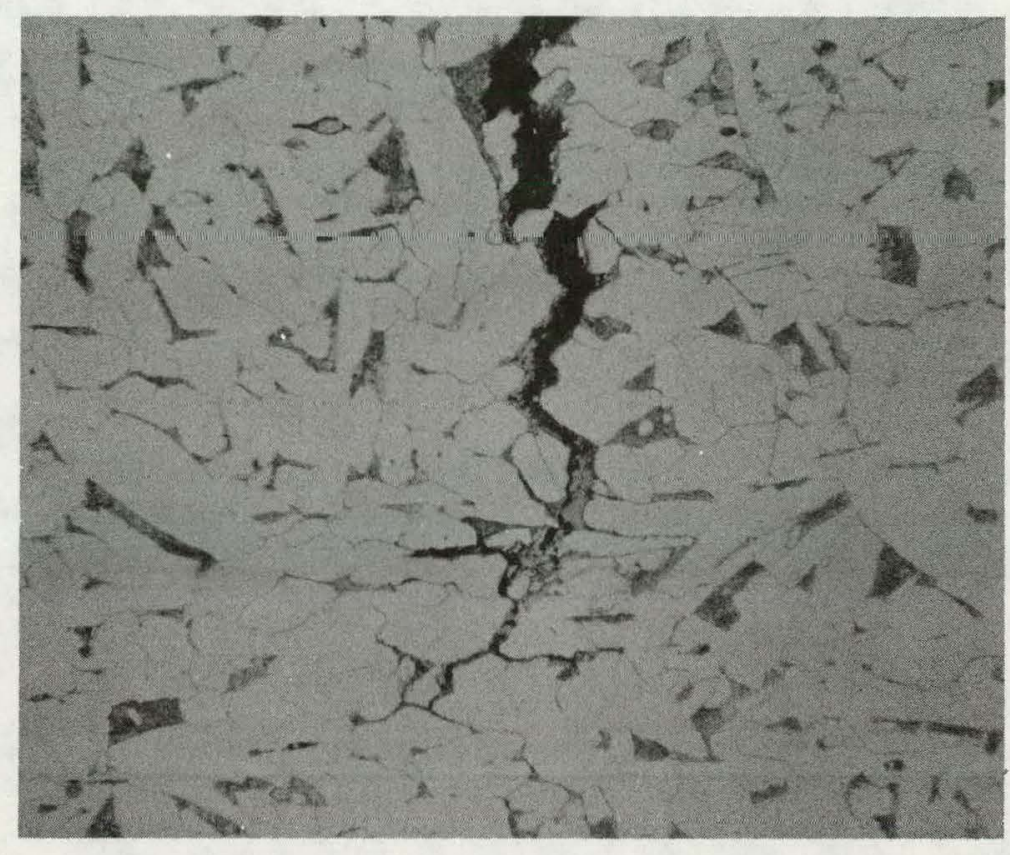

FIGURE 6. Intergranular Cracking of A 285-B Steel in ConstantCurrent Tensile Test. 
$221-F$
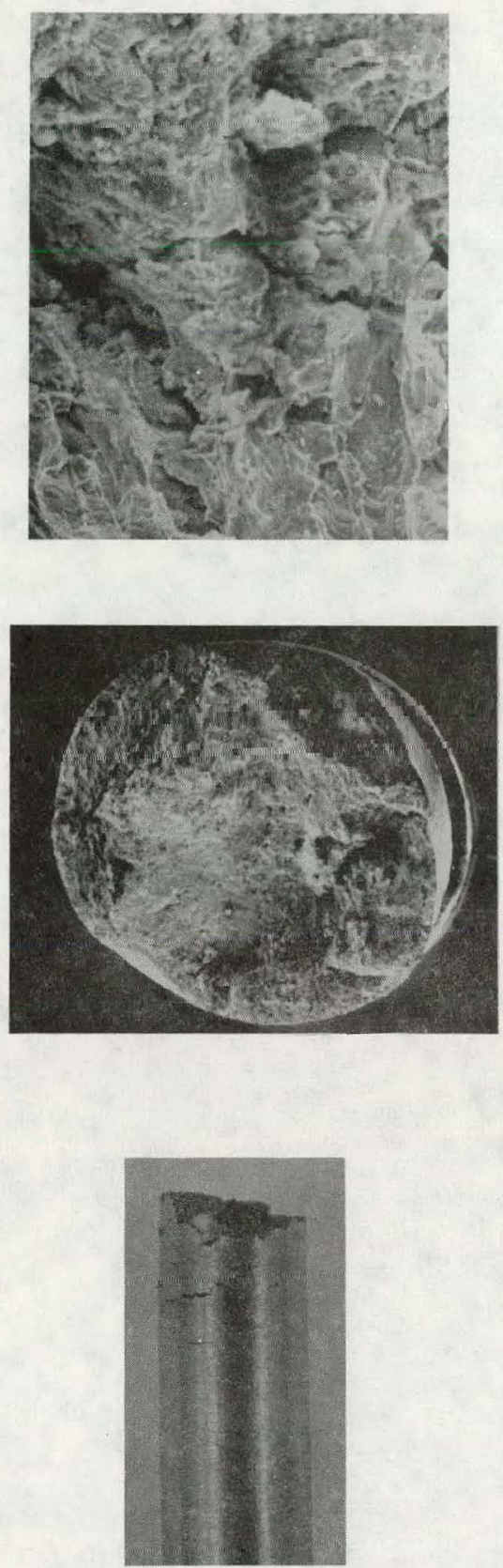

$\mathrm{H}-13$

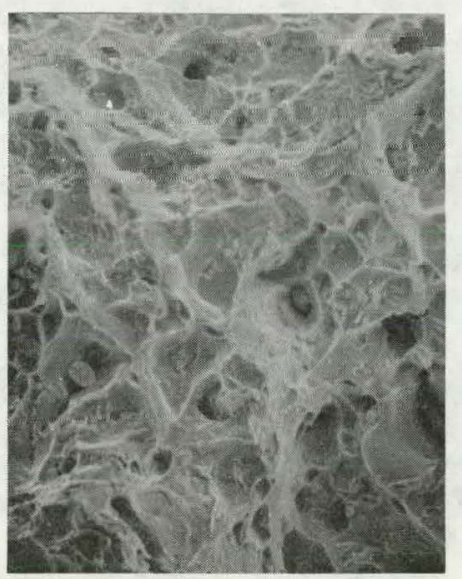

$50 \mu \mathrm{m}$

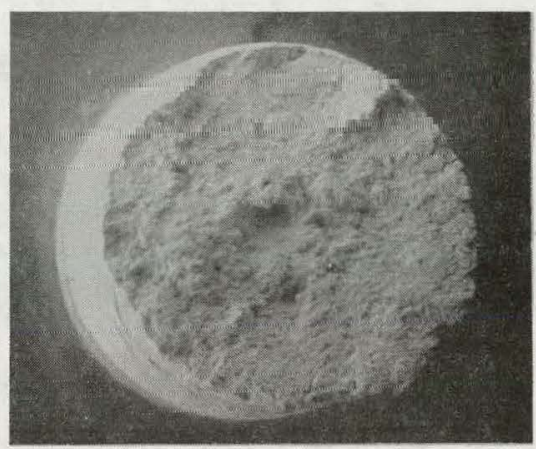

$\llcorner\mathrm{mm}$

Half of Fracture Surface
$H-9$
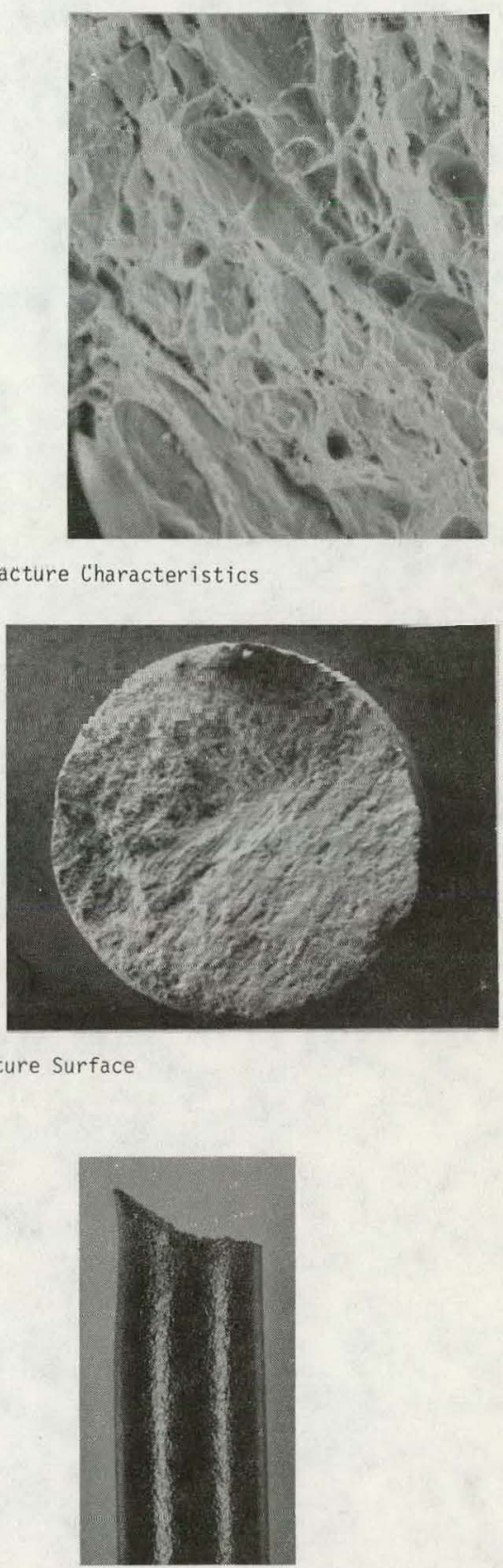

Portion of Gage Length at Fracture Incation

$4 \mathrm{~mm}, 1$

FIGURE 7. Fracture Characteristics of A 285-B Steel in $0.2-\pi \mathrm{I} A / \mathrm{cm}^{2}$ Tensile Test 


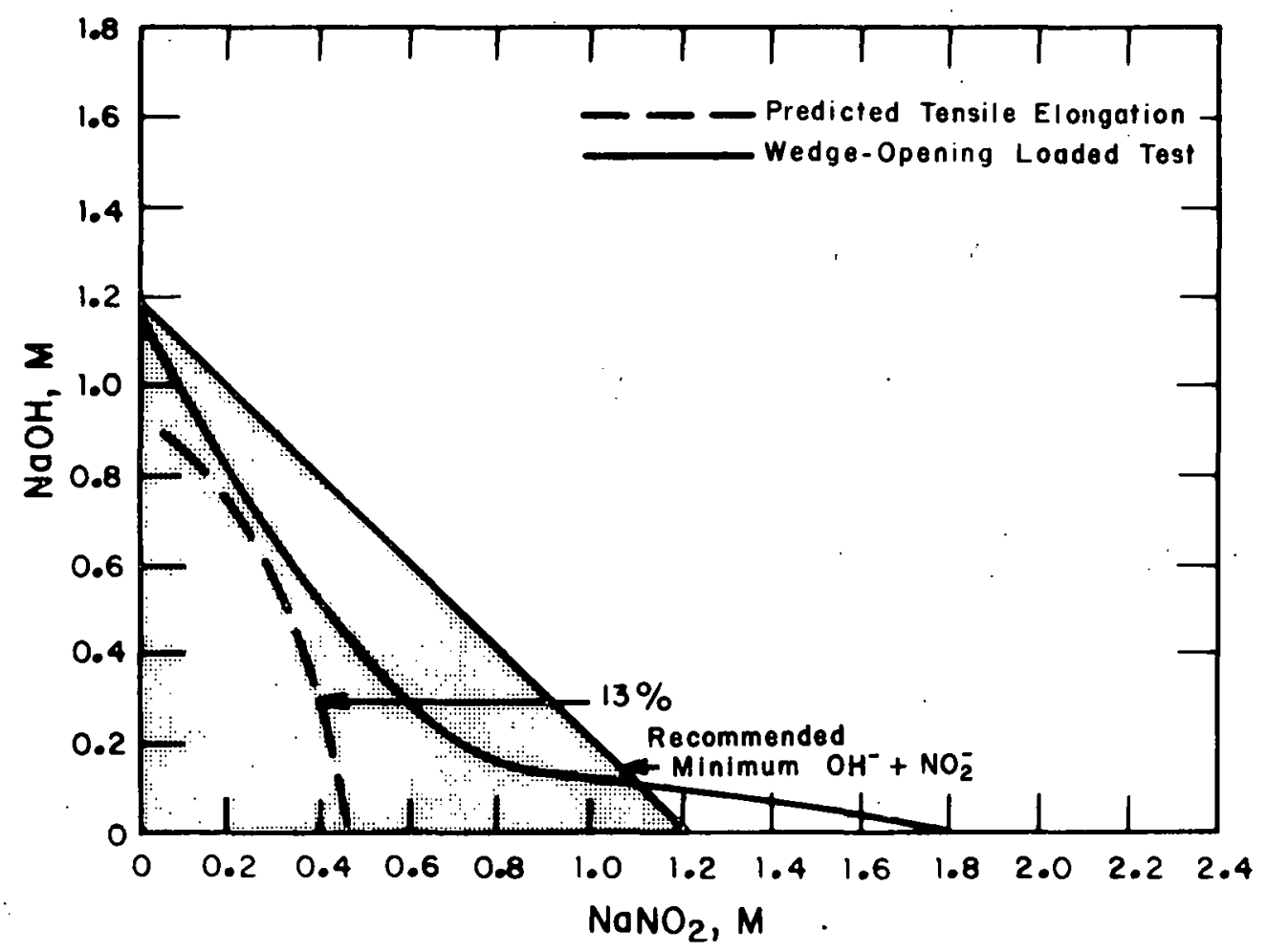

FIGURE 8. Effect of $\mathrm{NaNO}_{2}$ and $\mathrm{NaOH}$ on Stress Corrosion Cracking of $\mathrm{A} 285-\mathrm{B}$ Steel in $5 \mathrm{M} \mathrm{NaNO}$ at $97^{\circ} \mathrm{C}$ 